\title{
Parameatal Urethral Cyst: A Case Report
}

\author{
Parameatal Üretral Kist: Olgu sunumu
}

\author{
Hasan Hüseyin Tavukçu', Naşide Mangır², Bekir Özgür Dokanakoğlư ${ }^{3}$ Tufan Tarcan ${ }^{4}$ \\ 'Istanbul Bilim University Faculty of Medicine, Department of Urology, Istanbul, Turkiye \\ ${ }^{2}$ The University of Sheffield, Department of Materials Science and Engineering, Sheffield, United Kingdom \\ ${ }^{3}$ Karaman State Hospital, Clinic of Pathology, Karaman, Turkiye \\ ${ }^{4}$ Marmara University Faculty of Medicine, Department of Urology, İstanbul, Turkiye
}

\begin{abstract}
A 17-year-old boy presented with $15 \mathrm{~mm}$ swelling on the left side of his urethral meatus. He did not report any voiding symptoms. He was seeking medical treatment due to cosmetic concerns. Parameatal urethral cysts are benign conditions that are rarely reported in the literature. We performed complete excision of the cyst as previously suggested by some authors. On postoperative follow-up, there were no findings of voiding difficulty and cosmetic problem.
\end{abstract}

Keywords: Case, cyst, urethral meatus

\section{öz}

On yedi yaşında erkek hasta üretral meatusta $15 \mathrm{~mm}$ şişlik ile başvurdu. Değerlendirmede hasta işeme ile ilgili şikayet bildirmedi. Hasta kozmetik amaçı tedavi arayışındaydı. Genç erkeklerde oldukça nadir görülen parameatal üretral kist benign bir durum olup literatürde olgu sayısı oldukça azdır. Kiste literatür önerisine uygun şekilde tam eksizyon uygulandı. Postoperatif takibinde hastanın hiçbir problemi olmadı.

Anahtar Kelimeler: Olgu, kist, üretral meatus

\section{Introduction}

Parameatal urethral cyst (PUC) is a rare clinical entity seen mainly in boys although cases in girls, infants and adults have also been reported. PUC cases are most frequently reported in post-pubertal boys (1). The most common reason for a hospital admission has been related to cosmetic concerns, however, complaints of voiding difficulty or painful urination have also been reported $(2,3)$. The recommended treatment for a PUC is complete surgical excision of the cyst $(1,2)$. In this case report, we present a 17-year-old male patient with a PUC and a review of the existing literature.

\section{Case Presentation}

A 17-year-old male patient was admitted to our outpatint clinic with the complaint of penile swelling. On further inquiry, it was understood that the swelling developed over years after he was circumcised at the age of 7 years. He denied any voiding difficulty at any time. His only complaint was related to cosmetic concerns. On physical examination, a 15-mm soft, cystic lesion located to the left of the urethra was detected (Figure 1). The patient consented to complete surgical excision of the cyst. The cyst excision was performed under regional anesthesia. During the surgical procedure, the cyst was found to extend to the urethral tissue. The cyst was completely resected from the surrounding tissues without bursting it. The operation was completed without any complication (Figure 2). On histologic examination, a cystic structure lined by a transitional epithelium was reported (Figure 3). At follow-up visit after 6 months of the operation, the patient did not have any complaints.

\section{Discussion}

PUC is a urethral lesion that can occur in children and young adults and there is limited number of case reports in the

Correspondence: Hasan Hüseyin Tavukçu MD, İstanbul Bilim University Faculty of Medicine, Department of Urology, İstanbul, Turkiye

Phone:+90 2163756565 E-mail: hhtavukcu@yahoo.com

Received: 25.01.2016 Accepted: 15.03.2017

Cite this article as: Tavukçu HH, Mangır N, Dokanakoğlu BÖ, Tarcan T. Parameatal Urethral Cyst: A Case Report. J Urol Surg 2017;4:88-90.

๑Copyright 2017 by the Association of Urological Surgery / Journal of Urological Surgery published by Galenos Publishing House. 
literature about this condition. The largest series is published by Willis et al. (1) in 2011 which reported 18 pre-pubertal boys. Other than this series, Shiraki (4) reported 9 cases in 1975. After these two big series, cases of 3-4 patients have been reported in the English literature and, in Japanese literature, this entity has been reported more frequently (5). The reported cases were covering an age distribution ranging from infancy to puberty and no associated urological abnormalities were recognized. On examination of the urinary system, no abnormality was detected in our patient. Very few patients were symptomatic and the symptoms include decrease in caliber of the urine stream and

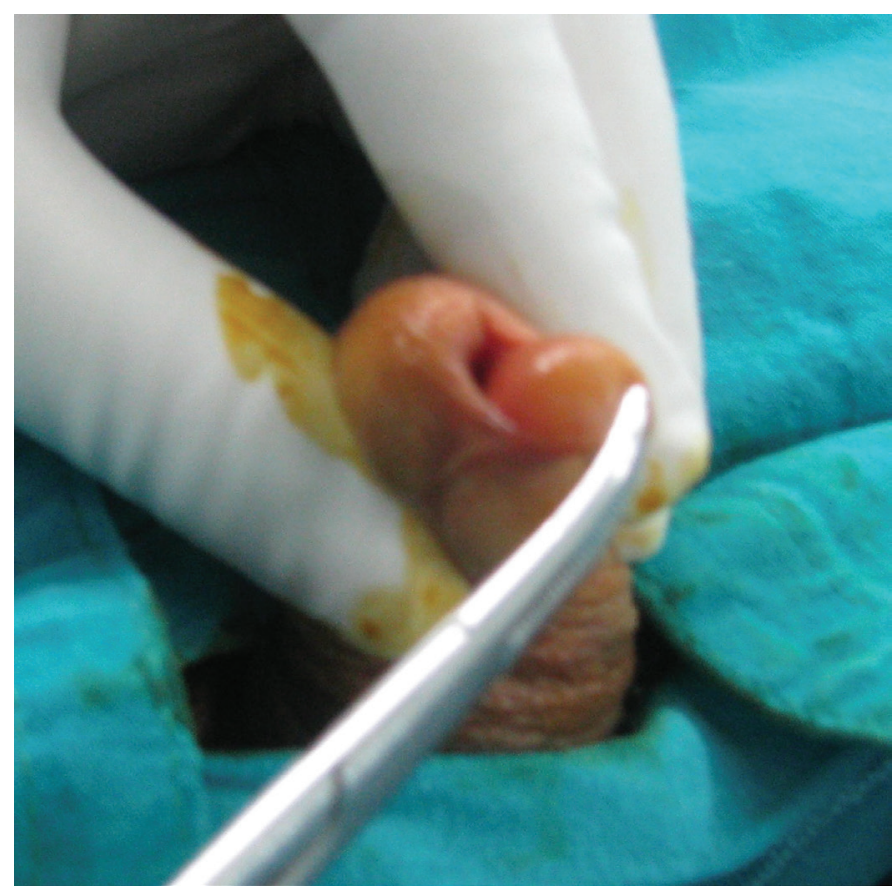

Figure 1. Preoperative appearance

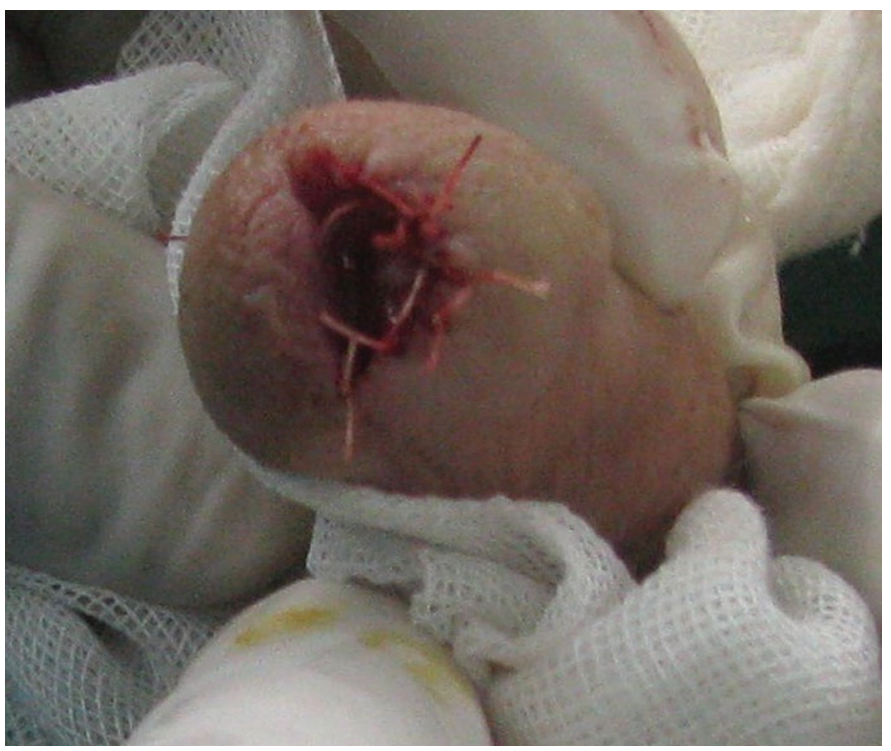

Figure 2. Postoperative appearance poor urinary flow (2). Vecchioll Scaldazza (6) reported a case of urinary retention due to a PUC in a 17-year-old female patient. Although PUC gives an impression that it might have an effect on urination, most patients are asymptomatic. Like most of the other cases, our patient wanted to undergo a surgical excision due to cosmetic reasons.

Although there are theories about the etiology of PUC, none of them are universally accepted. Lantin and Thompson (7) suggested that PUCs are remnants of tissue that occur after the separation of the foreskin from the glans penis. Other authors argued about urethral fusion anomalies, median raphe cysts or occlusion of paraurethral ducts. Development of cysts secondary to paraurethral duct inflammation has also been suggested by some authors $(5,8,9,10)$. In our patient, no sign of any infection was present and the histologic examination did not show any inflammation. In a series by Willis et al. (1), a pathologic evidence of inflammation was present in 1 case. PUC can be congenital or acquired as in our case. There is no data in the literature regarding the effect of any hormonal influence. We did not need to do any hormone test in our patient due to the absence of any associated urologic abnormalities.

Various types of tissues have been revealed by pathologic examination of the cyst structure. Similar to those of Otsuka et al. (8), Willis et al. (1) reported a transitional, squamous, columnar epithelium and combinations of any of the two in 6 patients. Papali et al. (10) reported columnar and cuboidal types as the most frequently seen pathologic findings. Otsuka et al. (8) classified PUC pathologically, in order of frequency, as urethral, epidermal and combination of the two (mixed). The pathologic evaluation in our patient revealed transitional epithelium derived from the urethral tissue, consistent with the literature.

The recommendations of Willis et al. (1) can be considered in deciding the treatment approach to the cysts. In infants, follow-up until the age of 6 months is recommended due to the risks associated with anesthesia and the possibility of

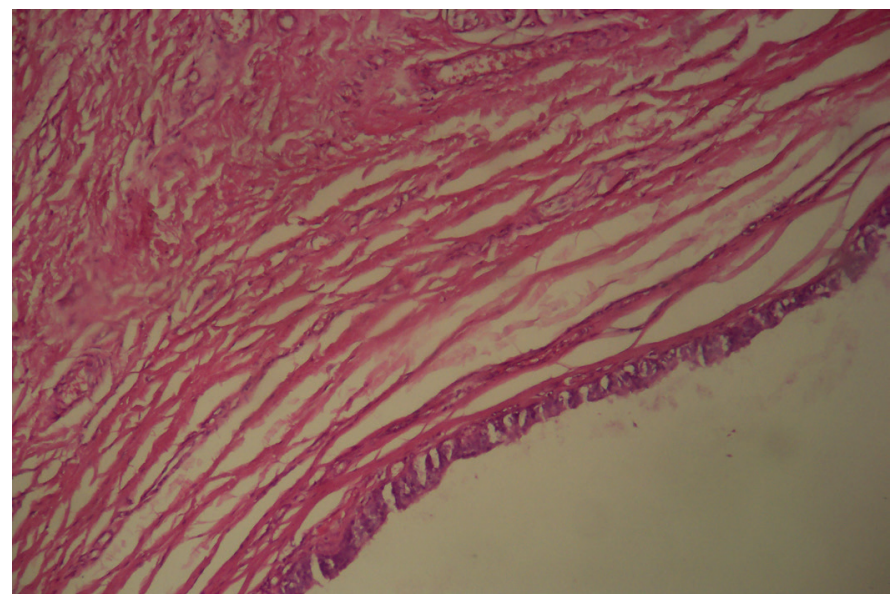

Figure 3. Microscopic appearance 
spontaneous resolution. If the cyst does not resolve, a surgical intervention can be considered. In late childhood, spontaneous resolution occurs more rarely, hence, a surgical intervention can be recommended. Besides, it is worth noting that most of the cysts are asymptomatic and the size of the cyst does not generally increase over time. Also, a recurrence was not reported after complete surgical excision in the series of Willis et al. (1). The aspiration of the cyst or the opening the cyst wall has been reported to cause a cyst recurrence (9). In the light of this knowledge, we have performed a complete surgical excision of the cyst under regional anesthesia in our patient. The skin covering glans penis and the urethra were sutured with absorbable suture material. Although meatal stenosis has not been reported in the literature, we have left the urethral meatus wide. The patient was followed up with a urethral catheter for 1 day and, after 6 months of follow-up, no recurrence or meatal stenosis was observed. Depending on the age and cooperation of the patient, this procedure might also be performed under local anesthesia whereas regional anesthesia can be more comfortable as in our case.

PUC is a benign condition that is generally asymptomatic and that is rarely related to infection or inflammation. Cosmetically, satisfactory clinical outcomes can be obtained after surgical excision without any recurrences.

\section{Ethics}

Informed Consent: Consent form was filled out by the participant.

Peer-review: Externally peer-reviewed.

\section{Authorship Contributions}

Surgical and Medical Practices: H.H.T., Concept: H.H.T., Design: H.H.T., Data Collection or Processing: H.H.T., B.Ö.D., Analysis or Interpretation: H.H.T., N.M., Literature Search: H.H.T., Writing: H.H.T., T.T.

Conflict of Interest: No conflict of interest was declared by the authors.

Financial Disclosure: The authors declared that this study received no financial support.

\section{References}

1. Willis $\mathrm{HL}$, Snow BW, Cartwright PC, Wallis MC, Oottamasathien $\mathrm{S}$, deVries $\mathrm{C}$. Parameatal urethral cysts in prepubertal males. J Urol 2011;185:1042-1045.

2. Onaran M, Tan MO, Camtosun A, Irkkilata L, Erdem O, Bozkırlı I. Parameatal cyst of urethra: a rare congenital anomaly. Int Urol Nephrol 2006;38:273-274.

3. Stovall TG, Muram D, Long DM. Paraurethral cyst as an unusual cause of acute urinary retention. J Reprod Med 1989;34:423-425.

4. Shiraki IW. Parameatal cysts of the glans penis: a report of 9 cases. J Uro 1975; 114:544-548.

5. Nakame Y, Yoshida K, Kaneoya F, Negishi T. Parameatal urethral cyst: a report of 2 cases and review of 32 cases in Japan. Hinyokika Kiyo 1984;30:695699.

6. Vecchioli Scaldazza C. Acute urinary retention in a young woman by parameatal urethral cyst. Arch Ital Urol Androl 2006;78:27-28.

7. Lantin PM, Thompson IM. Parameatal cysts of the glans penis. J Urol 1956;76:753-755

8. Otsuka $\mathrm{T}$, Ueda $\mathrm{Y}$, Terauchi M, Kinoshita Y. Median raphe (parameatal) cysts of the penis. J Urol 1998;159:1918-1920.

9. Oka M, Nakashima K, Sakoda R. Congenital parameatal urethral cyst in the male. Br J Urol 1978;50:340-341.

10. Papali AC, Alpert SA, Edmondson JD, Maizels $M$, Yerkes $E$, Hagerty J, Chaviano A, Kaplan WE. A review of pediatric glans malformations: a handy clinical reference. J Urol 2008;180(Suppl 4):1737-1742. 